Sri Lankan J. Biol. 2018, 3 (2): 9-23

DOI: http://doi.org/10.4038/sljb.v3i2.23

\title{
MORPHOMETRIC PHENOTYPES AND MOLECULAR IDENTIFICATION OF FASCIOLA SPECIES ISOLATED FROM CATTLE IN ILORIN, NORTH-CENTRAL NIGERIA
}

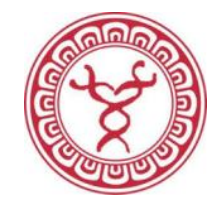

\author{
Iyiola O. A. ${ }^{1}$, Shittu $0 .{ }^{2}$, Owolodun O. A. ${ }^{1}$, Animasaun D. A. ${ }^{3}$ and Udeze, A. $0 .{ }^{4}$ \\ ${ }^{1}$ Cell Biology and Genetics Unit, Department of Zoology, University of Ilorin, P.M.B 1515, Ilorin Kwara state, \\ Nigeria. \\ ${ }^{2}$ Parasitology Unit, Department of Zoology, University of Ilorin, P.M.B 1515, Ilorin, Kwara state, Nigeria. \\ ${ }^{3}$ Department of Plant Biology, University of Ilorin, P.M.B 1515, Ilorin, Kwara state, Nigeria. \\ ${ }^{4}$ Department of Microbiology, University of Ilorin, P.M.B 1515, Ilorin, Kwara state, Nigeria
}

\section{Abstract}

Fascioliasis is a serious infectious parasitic disease of human and domestic ruminants. It is caused by the common liver flukes Fasciola hepatica and Fasciola gigantic and it is of public health concern in some countries of the world. Species-level identification of these species using only morphological methods is unconvincing, unreliable and sometimes difficult. Molecular methods enhance the prospects of species-level identifications using a well established and highly reliable DNA-based approach. We used PCR-RFLP analysis for precise identification of Fasciola species collected from Nigeria. One hundred Fasciola adult worms were collected from selected abattoirs in Ilorin, North-central Nigeria. The parasitic worms were first identified by morphometric analysis using AmScope digital camera fastened to the ocular eye piece of the light microscope. For the molecular identifications, genomic DNA was extracted, Polymerase Chain Reaction (PCR) technique and RFLP were used to characterise the Fasciola adult worms. Morphometric data showed that 70 out of the 100 Fasciola adult worms have characteristic features similar with that of $F$. gigantica as described from previous studies while the remaining 30 adult worms have characteristics that deviate from that of $F$. gigantica but did not confirm with characteristic features of $F$. hepatica. Agarose gel electrophoresis result confirmed successful amplification of two gene regions of Sodium Dehydrogenase I (ND1) from mitochondrial DNA of Fasciola spp. The PCR-RFLP analysis did not show any noticeable genetic variation in the Fasciola adult worms. We suggest more studies to be done using DNA sequence analysis and other molecular markers such as random amplified polymorphic DNA (RAPD) and simple sequence repeat (SSR) to better understand the genetic variability and population structure within Fasciola spp. in Nigeria.

Keywords: Fasciola gigantica, Fasciola hepatica, PCR-RFLP assay, molecular characterization, genomic DNA

*Corresponding author: E-mail: iyiola.oa@unilorin.edu.ng

Received date: 01/03/2018, Accepted date: 05/05/2018

https://orcid.org/0000-0003-2406-6736

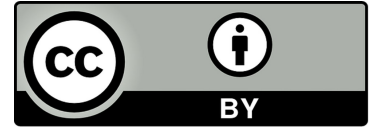

This is an open-access article distributed under the terms of the Creative Commons Attribution 4.0 International License, which permits unrestricted use, distribution and reproduction in any medium provided the original author and source are credited.

Sri Lankan Journal of Biology 3(2)
9

June 2018 


\section{Introduction}

Fasciola gigantica and Fasciola hepatica are common liver flukes causing fascioliasis, one of the most important helminth infections of human and livestock (Mas-Coma, 2005). Fascioliasis is a disease of veterinary and economic importance all over the world including Nigeria because it causes morbidity, weight loss and sometimes mortality among cattle (Tsegaye et al., 2011). Fasciola is very cosmopolitan in distribution, being found throughout all regions of the world, including temperate, tropical and subtropical regions. Infection is found in temperate and tropical areas where sheep and cattle are raised and in humans, typically where they consume raw watercress (Mas-Coma et al., 2009). Infection with $F$. gigantica, on the other hand, is found more commonly in tropical and subtropical regions of the world (Mas-Coma et al., 2014). The presence of both F. gigantica and F. hepatica, and the existence of intermediate forms, has been reported in livestock from Iran (Rokni et al., 2010; Amer et al., 2011), Egypt (Marcilla et al., 2002; Periago et al., 2008; Dar et al., 2012; El-Rahimy et al., 2012), Niger (Ali et al., 2008), Japan (Itagaki et al., 1998, 2005; Ichikawa and Itagaki, 2010), Korea (Agatsuma et al., 2000), China (Huang et al., 2004; Liu et al., 2014) and Vietnam (Le et al., 2008). A number of studies revealed single species infections of $F$. hepatica, reported in Tunisia, Algeria and Italy (Garippa, 2009; Farjallah et al., 2013) and F. gigantica has been reported in India (Velusamy et al., 2006; Prasad et al., 2008; Raina et al., 2013) and Mauritania (Amer et al., 2011). In addition, fascioliasis has been recognized as a major threat to public health in human and farm animals. However to reduce the risk of contracting fascioliasis, enhance its management and control, accurate identification of these species is a crucial and important step towards the disease control strategy and management. Species-level identification of these two common Fasciola species using only morphological methods is unconvincing, unreliable and sometimes difficult to discriminate by taxonomists (Marcilla et al., 2002). Periago et al. (2008) investigated phenotypic analysis of Fasciola hepatica/Fasciola gigantica intermediate forms in Egypt and Iran; the first of its kind in Africa. This study reported intermediate forms otherwise referred to as Fasciola species-like in Egypt and Iran where they used grouping variables such as body roundness, body length divided by maximum body width, and distance between the ventral sucker and the posterior end of the body (BR, $\mathrm{BL} / \mathrm{BW}$ and VS-P criteria).

Afshan et al., (2014) reported on the phenotypes of intermediate forms of Fasciola hepatica and F. gigantica from Central Punjab, Pakistan. Fasciolid populations from the studied area were grouped according to the maximum and minimum values of given differentiating morphological measurements. Periago et al., 2006 also observed an intermediate form of Fasciola species. Ghavami et al. (2009) and Baran et al., (2016) elucidated that the mean of morphometric values in flukes from sheep was greater than those of cattle in Iran and Baran, respectively. Genotypic characterisation to support established phenotypic intermediate forms were carried out as reported by other authors and it was discovered that ITS2 fragment of 535bp amplified specimens, showed no variation at the species-specific nucleotide sites 230, 340 and 341 
(Ghavami et al., 2009). DNA-based methods have been used as a reliable tool to identify biological diversity between the two common Fasciola species (Shafiei et al., 2013; Barker et al., 1993; Yakhchali et al., 2015; Itagaki and Tsutsumi, 1998; Marcilla, et al., 2002). Le et al. (2008) reported that in Vietnam, Fasciola gigantica is the dominating species, while an "intermediate Fasciola species" or " $F$. hepatica-like fluke", has been reported in humans, cattle and buffaloes. Molecular techniques using PCR-RFLP assay have been previously used for genetic identification of Fasciola species obtained from Japan on the basis of DNA sequences of ribosomal and mitochondrial DNA markers (Itagaki et al., 1998; 2005; Marcilla et al., 2002; Shafiei et al., 2013). Yakhchali et al. (2015) observed that PCR-RFLP analysis was able to differentiate $F$. hepatica from $F$. gigantica. While the phylogenetic reconstruction justified, to some extent, the morphological diagnosis, it failed to segregate $F$. hepatica from $F$. gigantica identified in previous studies. For effective drug and ecological intervention in Nigeria, there is an urgent need to differentiate between the fasciolid species, due to their distinct epidemiological, pathological and control characteristics. Unfortunately, coprological, immunological and pathological diagnosis may be unreliable, hence the need to establish phenotypic and genotypic distinctions in Fasciola species in Nigeria. In addition, there is limited documentation on molecular identification of these two common Fasciola spp in Nigeria. This knowledge gap hinders the understanding of the prevalence and dynamic transmission of fascioliasis. In the present study, we used standard morphological and molecular methods to identify and characterize Fasciola spp obtained from slaughtered cattle in Ilorin, Nigeria with the aim to investigate phenotypic and genotypic divergence existing between the hepatic flukes, Fasciola hepatica and F. gigantica.

\section{Material and Methods}

\subsection{Study Populations}

The fasciolid populations collected from liver of slaughtered cattle at various abattoirs in the four municipal local government areas in Ilorin, Nigeria were grouped according to the maximum and minimum values of the morphological measurements as proposed by Periago et al. (2006) into Fasciola hepatica, Fasciola gigantica and Fasciola sp.

\subsection{Parasite sample}

Fasciola adult worms $(\mathrm{n}=100)$ were collected from four local abattoirs in Ilorin, Northcentral Nigeria during postslaughter inspection from livers of naturally infected cattle, sheep and goat. Parasitic flukes were examined in collaboration with the veterinary doctors assigned to the abattoirs. Fresh adult worms were washed thoroughly in physiological saline, fixed in $95 \%$ ethanol and stored at $-20^{\circ} \mathrm{C}$ until further use for morphometric analysis, genomic DNA extraction and other molecular analyses.

\subsection{Slide Preparation}

A single adult fluke was chosen at random from each specimen bottle (a specimen bottle contains adult flukes collected from each infected animal). The selected adult worms were fixed for 20 minutes in 
sucrose hypotonic solution. The worms were then introduced into a petri dish containing prepared aceto-orcin standardized media for 30 mins, to allow proper staining of the internal organelles for easy identification and measurement. Each stained worm was spread between two glass slides and held firmly with cellophane tapes at both edges (Hussein and Khalifa, 2010).

\subsection{Observation and Measurement Techniques}

The slides were examined under a stereo microscope and the images viewed on a computer screen with the aid of an AmScope digital camera (AmScope Microscope Digital Camera 3.1MP APTINA Colour CMOS) fastened to the ocular eye piece of the microscope.

\subsection{Morphometric Identification}

Biometric characters were measured according to Periago et al., (2006). The parameters measured include: Body length (BL), Maximum body width (BW), Body width at ovary level (BWOv), Body perimeter (BP), Body roundness (BR), Cone length (CL), Cone width (CW), Maximum diameter of oral sucker (OS max) and Minimum diameter of oral sucker (OS min). Also, Maximum diameter of ventral sucker (VS max), Minimum diameter of ventral sucker (VS min), Distance between the anterior end of the body and the ventral sucker (A-VS), Distance between the oral sucker and the ventral sucker (OS-VS), Distance between the ventral sucker and the union of the vitelline glands (VS- Vit) and Distance between the union of the vitelline glands and the posterior end of the body (Vit-P) Distance between the ventral sucker and the posterior end of the body (VS-P).
Other morphometric features considered are Pharynx length (PhL), Pharynx width (PhW), Testicular space (taking both testes together) length (TL), Testicular space width (TW), Testicular space perimeter (TP), Body area (BA), Oral sucker area (OSA), Ventral sucker area (VSA), Pharynx area (PhA) and Testicular space area (TA).

\subsection{Derived Body Ratio Parameters}

Ratios of certain body parameters were determined, which includes: Body length to body width (BL/BW), Body width at ovary level to cone width (BWOv/CW). Oral sucker area to ventral sucker area (OSA/VSA) and the ratio of Body length to the distance between the ventral sucker and the posterior end of the body (BL/VSP).

\subsection{Measurement of body roundness}

The body roundness measurement was determined using the relation $\mathrm{BR}=$

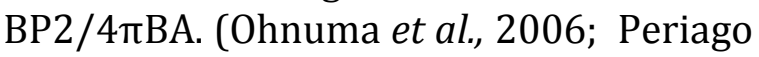
et al., 2008). All preliminary measurements and images were subsequently analyzed by image analysis software.

\subsection{DNA Extraction}

Two methods of DNA extraction were used i.e. Phenol-chloroform method and the use of Zymo Research genomic DNA Miniprep kit (Catalog No: D3050).

\subsection{DNA Extraction Using Phenol- Chloroform Method}

For genomic DNA extraction, freshly collected worms were extensively washed in physiological saline and fixed in 70\% ethanol. A portion of the apical and lateral 
zone of adult Fasciola sample was removed and crushed. DNA from the crushed materials was extracted following the listed procedures: $500 \mu \mathrm{l}$ of lysis buffer and $8 \mu \mathrm{l}$ of proteinase $\mathrm{K}$ were added to the sample and incubated overnight at $37^{\circ} \mathrm{C}$. Subsequently, $100 \mu$ l of phenol-chloroform was added and centrifuged at 1000 revolutions/10 min (rpm) at $25^{\circ} \mathrm{C}$. Top aqueous phase was removed and absolute alcohol was used to precipitate the DNA. Extracted DNA was diluted in TE buffer and stored at $20^{\circ} \mathrm{C}$ until used for PCR analysis.

\subsection{DNA Extraction Using Zymo-Spin Kit}

Genomic DNA was extracted using ZymoSpin $^{\text {TM }}$ kit (Zymos Research, USA) following the manufacturer's instructions. The DNA concentration and purity were checked by evaluating the absorbance ratio $A 260 \mathrm{~nm} / \mathrm{A} 280 \mathrm{~nm}$ using a Beckman DU-640B Spectrophotometer. The eluted DNA was stored below $-20^{\circ} \mathrm{C}$ until the next stage of molecular analyses.

\subsection{Polymerase chain reaction (PCR)}

In this study, the PCR experiments were carried out using $50 \mu \mathrm{l}$ final reaction volume consisting of $2 \mathrm{x}$ PCR master mix (QIAGEN, Hilden, Germany), 300 nM of forward and reverse primers. Primer sequences used are listed in Table 3 . Genomic DNA (300-500 ng) from Fasciola spp was used as the template. The PCR cycling conditions was $96^{\circ} \mathrm{C}$ for $1 \mathrm{~min}$. followed by 35 cycles of: $94^{\circ} \mathrm{C}$ for $30 \mathrm{~s}$, $55^{\circ} \mathrm{C}$ for $30 \mathrm{~s}$, and $72^{\circ} \mathrm{C}$ for $1 \mathrm{~s}$. Reactions were terminated with a final extension of $72^{\circ} \mathrm{C}$ for $7 \mathrm{~min}$. The PCR cycling steps were optimized for product length and primer annealing temperature according to the manufacturer's guidelines.

\subsection{Agarose Gel Electrophoresis}

The isolated DNA was assessed according to standard agarose gel electrophoresis protocol on $1 \%(\mathrm{w} / \mathrm{v})$ agarose in $1 \mathrm{X} \mathrm{TBE}$ buffer. The success of the DNA extraction process and the integrity of the isolated DNA were assessed on $1 \%(\mathrm{w} / \mathrm{v})$ agarose in the buffer. The isolated DNA samples were prepared for loading into the well created by the comb in the set agarose by mixing $4 \mu \mathrm{l}$ of the extracted DNA sample with $1 \mu \mathrm{l}$ of the $5 \mathrm{X}$ loading dye. The $5 \mu \mathrm{l}$ mixture of sample and loading dye was loaded into well formed by the comb in the gel (a sample per well). The electrophoresis was run at 80 volts for 45 mins, after which the gel was viewed and photographed under gel documentation.

\subsection{Restriction fragment length polymorphism (RFLP) analysis}

A PCR mixture of $20 \mu \mathrm{l}$ was digested using restriction enzyme (New England Biolabs) at the recommended temperature for $2 \mathrm{~h}$. The restriction fragments were separated on $1 \%(\mathrm{w} / \mathrm{v})$ agarose in 1X TBE buffer and the size of DNA fragments was determined in comparison with a $100 \mathrm{bp}$ ladder (New England Biolabs).

\section{Results}

\subsection{Morphometric Analysis}

The specimens from the four abattoirs were grouped into Fasciola hepatica-like, Fasciola gigantica-like and Fasciola sp based on morphometric features such as Body Roundness (BR), Body Length to 
Body Width ratio (BL/BW) as well as the Distance between Ventral Sucker and Posterior End of the Body (VS-P). Comparing the range of values obtained from each abattoir, none of the fluke observed could be described as Fasciola hepatica. The samples were only tropical species Fasciola gigantica and the intermediate species Fasciola sp. based on the standard descriptor and criteria (Table 1). Comparison of the maximum values in each of the body measurements between Fasciola gigantica and Fasciola sp. showed that $F$. gigantica had the highest value. We observed that $66.67 \%$ of the measurements are greater in the specimens grouped as $F$. gigantica among the samples collected from Ipata while, $85.19 \%$ of the measurements were greater in Oja-Titun. In terms of percentage of total flukes examined, $74.07 \%$ was higher in Ipata-Oloje and $60 \%$ in Oko-Olowo. The intermediate populations from the four abattoirs differed to a great extent; whereas specimens from Ipata had low values of BL, BW, BP, CW, OS max, OS min, A-VS, OS-VS, VS-Vit, Vit-P, VS-P, TL, TW, TP, BA, OSA, TA as well as BL/BW, those from Oja-Titun had low maximum values of $\mathrm{BL}$, BW, BWOv, BP, BR, CL, CW, OS max, OS min, VSMax, VSMin, A-VS, OS-VS, VS-Vit, Vit-P, PhL, TL, TW, TP, BA, OSA, VSA and $\mathrm{BL} / \mathrm{BW}$. While the specimens from IpataOloje had the lowest maximum values of BL, BW, BWOv, BP, BR, CW, OS max, OS min, VSMax, VSMin, OS-VS, Vit-P, TP, BA, OSA, VSA, PhA, TA with BL/BW, the ones from Oko-Olowo had the lower maximum values of $\mathrm{BL}, \mathrm{BW}, \mathrm{BP}, \mathrm{BR}, \mathrm{CL}, \mathrm{CW}, \mathrm{OS} \max$, OS min, VSMax, VSMin, TL, TP, BA, OSA, VSA, TA and BL/BW as shown in Table 1.

Table 1. Comparative morphometric data of adults Fasciola gigantic and Fasciola spp isolated from cattle at four different abattoirs in Ilorin, North-Central, Nigeria

\begin{tabular}{|c|c|c|c|c|c|c|c|c|}
\hline Abatsoins & Ipata & & Oja-titun & & Ipata-Oloje & & Oka-Olawo & \\
\hline $\begin{array}{l}\text { Fascidala } \\
\text { species }\end{array}$ & $\begin{array}{l}\text { Fascid'a } \\
\text { gigarnica }\end{array}$ & Fasciola sp. & $\begin{array}{l}\text { Fasciala } \\
\text { giganitea }\end{array}$ & Fasciolas & $\begin{array}{l}\text { Fasciala } \\
\text { Egentica }\end{array}$ & Fasciola up. & $\begin{array}{l}\text { Facida } \\
\text { gigantica }\end{array}$ & Fazeiala sp. \\
\hline $\begin{array}{l}\text { Number of } \\
\text { adsilt flukes }\end{array}$ & 16 & 9 & 18 & 7 & 19 & 6 & 15 & 10 \\
\hline $\begin{array}{l}\text { Body Length } \\
\text { (BL) }\end{array}$ & $\begin{array}{l}30.01-42.32 \\
3393 \pm 3.29\end{array}$ & $\begin{array}{l}22.88 .30 .01 \\
26.78 \pm 2.90\end{array}$ & $\begin{array}{l}30.46-42.32 \\
35.51=2.60\end{array}$ & $\begin{array}{l}23.23-30.46 \\
27.12 \pm .46\end{array}$ & $\begin{array}{l}30.01-36.39 \\
32.56 \pm 1.97\end{array}$ & $\begin{array}{l}24.12 .2992 \\
28.18 \pm 2.07\end{array}$ & $\begin{array}{l}32.86-42.32 \\
34.88+2.42\end{array}$ & $\begin{array}{l}17.98-30.01 \\
25.64 \pm 3.87\end{array}$ \\
\hline $\begin{array}{l}\text { Mrovimen } \\
\text { Body Width }\end{array}$ & $4.04-10.52$ & 5.22 .9 .29 & $4.04-10.52$ & 4.29 .929 & $4.40-8.48$ & $5.59-6.01$ & $4.04-10.23$ & $4.29-8.41$ \\
\hline (Bw) & $6.51=1.48$ & $6.51=1.42$ & $6.98 \pm 1.82$ & $6.63 \pm 1.78$ & $6.15 \pm 1.18$ & $6.48=0.57$ & $6.15 \neq 1.40$ & $6.39=1.16$ \\
\hline $\begin{array}{l}\text { Body Width } \\
\text { At Orary }\end{array}$ & 2.75 .5 .37 & 2.27 .5 .70 & 2.75 .560 & $3.01-5.01$ & 287.691 & $3.86-5.70$ & 2.75 .5 .64 & 2.27 .5 .70 \\
\hline $\begin{array}{l}\text { Level } \\
\text { (BwOr) }\end{array}$ & $4.08=0.90$ & $4.19=1.13$ & $4.07=0.88$ & $3.99=0.56$ & $4.38=0.96$ & $4.82 \pm 0.77$ & $3.90=0.83$ & $3.68=1.13$ \\
\hline $\begin{array}{l}\text { Body } \\
\text { Perimeter }\end{array}$ & 6429.8350 & 62.67 .7098 & 64.29 .91 .52 & 64.69 .7698 & 62.15 .91 .10 & $61.86-8492$ & $63.50-91.52$ & 62.35 .84 .92 \\
\hline (BP) & $6796 \pm 4.84$ & $65.72 \div 1.82$ & $72.25 \times 8.07$ & $67.62 \pm 7.44$ & $69.10 \pm 7.14$ & $70.69=8.97$ & $72.57=10.21$ & $67.67 \pm 6.41$ \\
\hline $\begin{array}{l}\text { Body } \\
\text { Roundhess }\end{array}$ & $1.08-3.54$ & $1.84-3.55$ & $1.08-431$ & $1.84-4.22$ & $1.55-4.64$ & $1.99-4.06$ & $1.19-431$ & $184-422$ \\
\hline (BR) & $2.24 \pm 0.59$ & $2.62 \pm 0.56$ & $2.32 \neq 0.83$ & $2.79=0.90$ & $253=0.75$ & $283=0.73$ & $2.61=0.77$ & $3.01=0.90$ \\
\hline \multirow{2}{*}{$\begin{array}{l}\text { Cone Length } \\
\text { (CL) }\end{array}$} & $1.11-2.24$ & 0.79 .229 & $1.17-3.07$ & $0.79-2.49$ & $109 \cdot 2.18$ & 1. $19-1.44$ & $1.09-290$ & $106-229$ \\
\hline & $1.51=0.32$ & $1.37 \pm 0.46$ & $1.85=0.51$ & $1.71=0.53$ & $1.41 \pm 0.29$ & $1.32 \neq 0.096$ & $1.80=0.46$ & $1.30=371$ \\
\hline \multirow{2}{*}{$\begin{array}{l}\text { Cone Wiath } \\
\text { (CW) }\end{array}$} & 1.07 .3 .25 & 1.17 .2 .45 & 1.07 .3 .12 & 1.17 .225 & 1.15 .3 .25 & $208-2.75$ & $1.17-3.12$ & 1.25 .2 .75 \\
\hline & $1.85=0.53$ & $1.74 \pm 0.50$ & $1.73=0.45$ & $1.64=0.45$ & $185 \pm 0.54$ & $239 * 0.22$ & $1.70=0.46$ & $1.94 \pm 0.49$ \\
\hline
\end{tabular}


Table 1cont'd. Comparative morphometric data of adults Fasciola gigantic and Fasciola spp isolated from cattle at four different abattoirs in Ilorin, North-Central, Nigeria

\begin{tabular}{|c|c|c|c|c|c|c|c|c|}
\hline \multirow{2}{*}{$\begin{array}{l}\text { Abatán } \\
\text { Fatcida species }\end{array}$} & \multicolumn{2}{|l|}{ Ipata } & \multicolumn{2}{|l|}{ Oja-Titus } & \multicolumn{2}{|l|}{ IpataOloje } & \multicolumn{2}{|l|}{ Ola-Olewe } \\
\hline & $\begin{array}{l}\text { Fatcida } \\
\text { gigartica }\end{array}$ & Fatcidaspp & $\begin{array}{l}\text { Fascidala } \\
\text { gigartica }\end{array}$ & $\begin{array}{l}\text { Fasciola } \\
\text { spp }\end{array}$ & $\begin{array}{l}\text { Fatcidala } \\
\text { Egantica }\end{array}$ & Fatciola mp & $\begin{array}{l}\text { Fasciola } \\
\text { gigantica }\end{array}$ & Fatciolasp \\
\hline Number d adilt fukes & 16 & 9 & 18 & 7 & 19 & 6 & 15 & 10 \\
\hline $\begin{array}{l}\text { Distance Between Unice of } \\
\text { Vitelline Glasds Asd Posterior }\end{array}$ & 595.15 .98 & 5.75 .13 .65 & 6.05 .18 .45 & 5.75 .41 .49 & 595.1905 & $7.15-1697$ & $6.07 .17,40$ & $7.15-1697$ \\
\hline End (Vit-P) & $10.40 \pm 3.61$ & $9.03 \pm 2.67$ & $11.95 \div 4.27$ & $869 \pm 4.04$ & $11.32 \pm 393$ & $12.59=3.90$ & $12.59 \pm 4.28$ & $1024 \pm 289$ \\
\hline \multirow{2}{*}{$\begin{array}{l}\text { Distance Betwea VS And } \\
\text { Potenice End \& Body (VS.P) }\end{array}$} & $9.01-22.82$ & 1107.9 .76 & $901 \cdot 2282$ & 11.07 .17 .11 & $10.10-161$ & 14.51 .2 .14 & $13.61 \cdot 18.92$ & 893.20 .67 \\
\hline & $16.76 \pm 3.60$ & $14.47 \pm 2.43$ & $1622=292$ & $4.17=2.82$ & $15.30 \pm 3.04$ & $19.09 \neq 3.08$ & $16.39 \neq 1.98$ & $13.26=3.41$ \\
\hline \multirow[t]{2}{*}{ Pharyax Length (RhL) } & $0.49 \cdot 1.30$ & 0.39 .1 .37 & $0.76-1.45$ & 0.74 .1 .45 & 0.49 .130 & 039.134 & 0.78 .117 & 0.39 .1 .37 \\
\hline & $0.93=0.22$ & $0.97=0.31$ & $100=0.16$ & $1.07 \pm 0.19$ & $102=0.20$ & $1.06=0.34$ & $102 \pm 14$ & $1.10 \pm 0.27$ \\
\hline \multirow[t]{2}{*}{ Paryax Widh (PW) } & $0.10-0.19$ & 0.11 .0 .25 & 0.15 .023 & $0.14-0.25$ & $0.10-0.26$ & 0.11 .0 .19 & 0.13 .0 .19 & 0.11 .0 .25 \\
\hline & $0.15 \pm 0.02$ & $0.17 \div 0.04$ & $0.17 \pm 0.01$ & $0.19+0.02$ & $0.15 \div 0.04$ & $0.14=0.03$ & $0.17 \pm 0.02$ & $0.15=0.04$ \\
\hline \multirow[t]{2}{*}{ Testicaler Space Lagth (TL) } & 1155.19 .72 & $11.05 \cdot 13.05$ & 11.54 .25 .75 & 11.05 .15 .32 & 1164.21 .75 & 11.67 .24 .86 & 11.64 .25 .75 & 11.67 .24 .86 \\
\hline & $1406 \pm 2.89$ & $12.39 \div 0.79$ & $15.14 \div 4.09$ & $12.99 \div 3.64$ & $1491=3.16$ & $17,43 \pm 538$ & $15.23 \pm 4.47$ & $1485 \div 4.99$ \\
\hline \multirow[t]{2}{*}{ Testicular Space With (TW) } & 4.79 .6 .49 & 4.76 .596 & 490864 & 4.79 .605 & 4.78 .6 .73 & 4.98 .7 .56 & 490.753 & $4,76.7 .56$ \\
\hline & $3.48=0.59$ & $5.12=0.45$ & $6.18=0.97$ & $5.30 \pm 0.94$ & $536=0.60$ & $6.20=0.97$ & $394=0.76$ & $5.45 \pm 1.00$ \\
\hline \multirow{2}{*}{$\begin{array}{l}\text { Testicalar Space Parimetar } \\
\text { (TP) }\end{array}$} & 3253.52 .50 & 27.514298 & 3249.50 .75 & 33.0542 .51 & 3262.5250 & 27.51 .43 .70 & 32.49 .52 .50 & $33.10-41.74$ \\
\hline & $38.34=5.99$ & $31.01=1094$ & $3960=6.12$ & $35.21=5.77$ & $39.85=5.53$ & $32.51=15.22$ & $39.89 \div 7.67$ & $33.60=11.15$ \\
\hline
\end{tabular}

Key: Minimum - Maximum Measurements is Millimetres, "*Mean a SD

\subsection{PCR-RFLP Results}

3.2.1 Restriction digestion and agarose gel electrophoresis analysis

In order to investigate possible restriction fragment differences and genetic variation in the samples of Fasciola species collected, the amplified NDI sequences by PCR were analysed with AluI restriction endonucleases. When amplified PCR products of NDI gene were digested with the restriction enzyme AluI, sites in both species, and so we selected it to distinguish the two species without false negative. However, the enzyme produced similar restriction fragment patterns (the number and size of fragments) for Fasciola spp. This further confirmed that all the Fasciola adult worms collected and analysed by both morphometric and molecular methods in this study were F. gigantica. 


\subsection{Molecular Analysis Results}

Our data NDI gene sequences of the PCR products showed that all of the worms were $F$. gigantica (Fig 1, 2 and 3). Therefore we inferred from our observation that it is very likely that $F$. gigantica is the predominant Fasciola species in Nigeria. It is not surprising therefore that the molecular data corroborated the morphometric results which both showed the predominance of F gigantica in Nigeria.

However, this is not supported by the studies performed by Alasaad et al. (2011) in Spain and Ghavami et al, (2009) in Northwestern Iran, in which only Fasciola hepatica was reported. The results of this study is consistent with previous studies by Lin et al.,(2007); Le et al., (2008) and Ichikawa and Itagaki., (2010).who also reported intermediate species among Fasciola sp.

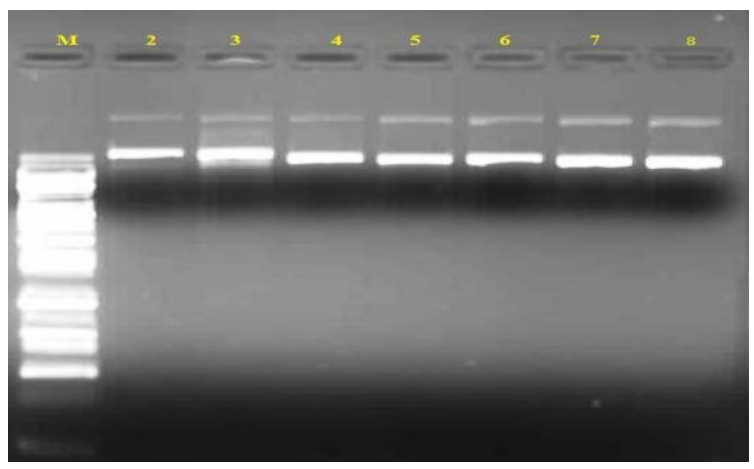

Figure 1. Agarose gel electrophoresis of genomic DNA isolated from Nigerian Fasciola adults worms. Lane 1: DNA ladder (M); Lane 2-8. Genomic DNA of Fasciola adult worms isolated from slaughtered cattle

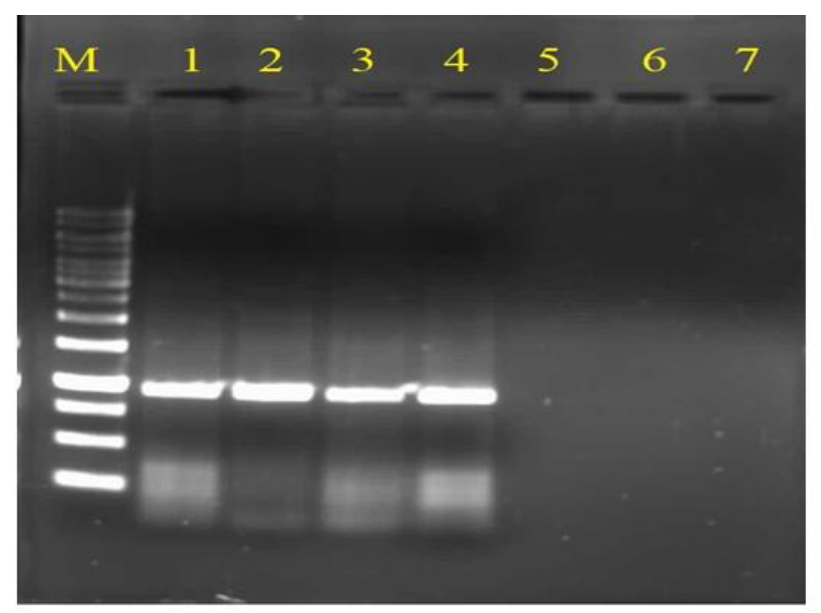

Figure 2. Agarose gel electrophoresis of mitochondrial NDI gene isolated from Nigerian Fasciola species. Lane 1: DNA ladder (M); Lane 1-4. PCR products of NDI gene (the samples isolated from slaughtered cattle); Lane 5-7 (negative control); Amplicon size:348bp

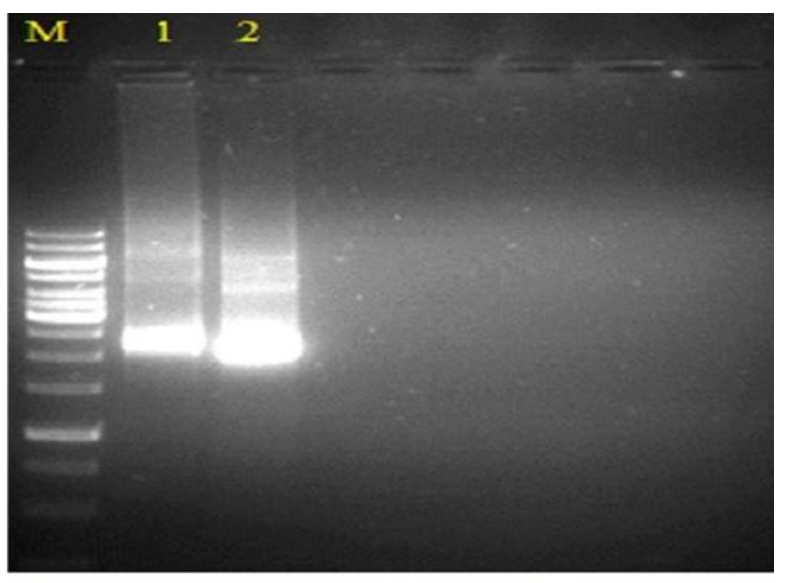

Figure 3. Agarose gel electrophoresis of mitochondrial NDI gene isolated from Nigerian Fasciola species. Lane 1: DNA ladder (M); Lane 1and 2 PCR products of NDI gene (the samples isolated from slaughtered cattle); Amplicon size:535bp 
PCR analysis of the NADH dehydrogenase subunit I (NDI) gene of Fasciola species did not show length heterogeneity between $F$. hepatica and $F$. gigantica. This is suggesting that there are no length polymorphisms among Fasciola mitochondrial genomes of samples collected from Ilorin. This may further suggest that all the Fasciola samples are $F$. gigantica as we expected that although $F$. hepatica and F. gigantica are closely related species, there are overwhelming evidences from previous findings that a high intraspecific variation exist between these Fasciola species (Karimi, 2008; Shafiei et al., 2013; Saki et al., 2011; Yakhchali et al., 2015; Itagaki and Tsutsumi, 1998; Marcilla et al., 2002).

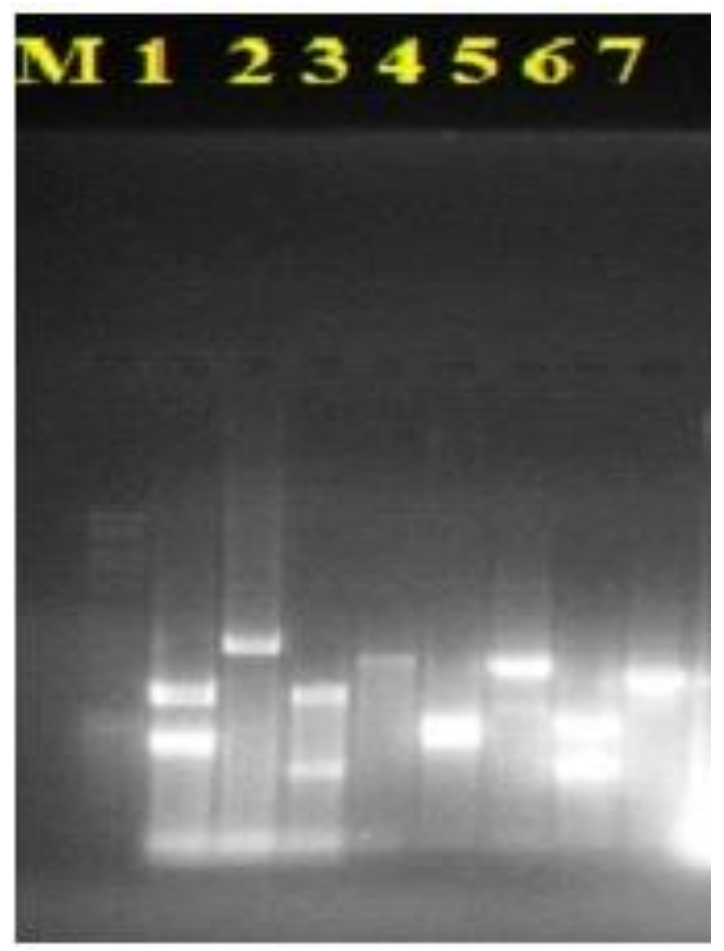

Figure 4. RFLP pattern of PCR products of Fasciola species digested with Alul (M) is 100bp DNA ladder. Lane 2, 4 and 6 are PCR products for control, lane $1,3,5$, and 7 are Fasciola species.
We therefore suggest that based on our result, the isolated samples are all Fasciola gigantica and in the tropical region of the world because they were all obtained from cattle. PCR-RFLP result of the restriction endonuclease did not show any noticeable distinction between $F$. hepatica and F. gigantica. This is not surprising as previous study by Huang et al., 2004 showed no variation in restriction patterns among multiple individuals from the same geographical locations. Similarly, restriction endonuclease analysis of Japanese Fasciola species showed that samples of $F$. hepatica were identical in restriction map with $F$. gigantica and no intraspecific variations were detected in the restriction maps of both species of Fasciola (Marcilla et al., 2002).

\section{Discussion}

The present study showed remarkable differences in morphometric indices among the liver flukes isolated from slaughtered cattle in four different abattoirs in Ilorin metropolis, Kwara state. Considering the variations observed within the parameters like BL, BW and VS-P and others measured in the studied samples, they are likely to be grouped into F. gigantica and Fasciola species (i.e. other forms). In terms of body width, $F$. gigantica showed the highest measurement of body width in the four abattoirs with the highest of $10.52 \mathrm{~mm}$ in Ipata and Oja-tuntun while the least body width of $4.04 \mathrm{~mm}$ was recorded in Ipata, Oja-titun and Oko-Olowo abattoirs for Fasciola sp. Also, body width at ovary level was higher in $F$. gigantica than Fasciola sp. group. Body perimeter was 
found to be higher for the $F$. gigantica group in all the abattoirs, with the highest of all measuring $91.52 \mathrm{~mm}$ found both in Oko-Olowo and Oja-Titun, however, the lowest measurement was also found in the $F$. gigantica group, measuring 61.86 $\mathrm{mm}$ as observed in the specimen for Ipata-Oloje abattoir. Body roundness and cone length were higher in Oja-Titun, Ipata-Oloje and Oko-Olowo abattoirs for F. gigantica, although, Fasciola sp. had the highest value in Ipata, it measured 3.55 $\mathrm{mm}$ for body roundness and $2.29 \mathrm{~mm}$ for cone length compared to the $3.54 \mathrm{~mm}$ and $2.24 \mathrm{~mm}$ observed, respectively for the market. The lowest body roundness and cone length were observed in Ipata and Oja-Titun for Fasciola spp. at $1.08 \mathrm{~mm}$ and $0.79 \mathrm{~mm}$ respectively, with the highest body roundness and cone length values being $4.64 \mathrm{~mm}$ in Ipata-Oloje and $3.07 \mathrm{~mm}$ in Oja-Titun.
The values obtained from both categories (i.e. F. gigantica and Fasciola sp.) overlap to a great extent. However, such overlapping was not observed for the grouping criteria (BR, VS-P and BL/BW), this is in agreement with the result reported by Periago et al. (2008). There were overlapping measurements between the two categories in some parameters but this was not found in the standard parameters (i.e. BL, CW, BA and BP) used for the grouping as postulated by Periago et al. (2006). Therefore, morphometric analysis done as the first step of identification has been able to show the phenotypes of these flukes.

Table 2. Morphometric comparison using ratios of body parameters

\begin{tabular}{|c|c|c|c|c|c|c|c|c|}
\hline \multirow{2}{*}{$\begin{array}{l}\text { Abattoins } \\
\text { Fasciola species }\end{array}$} & \multicolumn{2}{|l|}{ Ipata } & \multicolumn{2}{|l|}{ Oja-titun } & \multicolumn{2}{|l|}{ Ipata-Oloje } & \multicolumn{2}{|l|}{ Oko-Olowo } \\
\hline & $\begin{array}{l}\text { Fasciola } \\
\text { gigaritica }\end{array}$ & Fasciola spp & $\begin{array}{l}\text { Fasciola } \\
\text { gigantica }\end{array}$ & Fasciola spp. & $\begin{array}{l}\text { Fasciola } \\
\text { gigantica }\end{array}$ & Fasciola spp. & $\begin{array}{l}\text { Fasciola } \\
\text { gigantica }\end{array}$ & Fasciola spp. \\
\hline $\begin{array}{l}\text { Number of adult } \\
\text { flukes }\end{array}$ & 16 & 9 & 18 & 7 & 19 & 6 & 15 & 10 \\
\hline \multirow{2}{*}{$\begin{array}{l}\text { Ratio Between } \\
\text { Sucker Areas } \\
\text { (OSA VSA) }\end{array}$} & $0.22-1.16$ & $0.24-0.91$ & $0.32-1.16$ & $0.44-0.84$ & $0.18-1.16$ & 0.59 .0 .90 & $0.28-1.04$ & $0.24-0.93$ \\
\hline & $0.73 \pm 0.26$ & $0.54 \pm 0.27$ & $0.66 \pm 0.24$ & $0.63 \pm 0.22$ & $0.60 \pm 0.33$ & $0.80=0.12$ & $0.56 \pm 0.18$ & $0.53 \pm 0.25$ \\
\hline \multirow{2}{*}{$\begin{array}{l}\text { Ratio Between } \\
\text { Bwov and CW } \\
\text { (Bwov/CW) }\end{array}$} & $1.22-4.95$ & $1.62-3.25$ & $1.58-4.95$ & $1.83-3.25$ & $1.22-3.89$ & $1.51-2.52$ & $1.58-3.66$ & $1.35-2.40$ \\
\hline & $2.32=0.85$ & $2.48=0.61$ & $2.48 \pm 0.80$ & $2.51=0.72$ & $2.53=0.79$ & $2.03 \pm 0.41$ & $2.37 \pm 0.55$ & $1.92 \pm 0.38$ \\
\hline \multirow{2}{*}{$\begin{array}{l}\text { Ratio Between BL } \\
\text { and VS-P(BL/VS-P) }\end{array}$} & 1.47 .3 .98 & $1.48-2.24$ & 1.69 .3 .98 & $1.66-2.24$ & $1.47-3.24$ & 1.27 .200 & $1.74-2.68$ & $1.45-2.24$ \\
\hline & $2.14 \pm 0.63$ & $1.88 \pm 0.26$ & $2.27 \pm 0.52$ & $1.93 \pm 0.49$ & $2.21 \pm 0.48$ & $1.51 \pm 0.26$ & $2.17 \pm 0.36$ & $1.72 \pm 0.27$ \\
\hline
\end{tabular}

Key: Minimum - Maximum Measurements in Millimetres. " Mean $=$ SD 
Table 3. Gene of interest, gene location, name and primer sequence used PCR analysis

\begin{tabular}{|c|c|c|c|c|c|}
\hline $8 x$ & Gene & Gene Loatan & Name & Prista Sequence for FCR & $\begin{array}{l}\text { ExpededPCR } \\
\text { podud ise (bP) }\end{array}$ \\
\hline 1 & ND1 & Mitochondria DNA & Nd1F & 5.GTGGGGTCTGTTGCAGAGAT-3 & 348 \\
\hline 2 & ND1 & Mitóchoondráa DNA & Nd1 R & 5-CCCCAAACCAAAGCAACTAA-3 & \\
\hline 3 & NDI & Mitochondria DNA & Nd1F & 5-AAGGATGTTGCTTTGTCGTGG=3 & 535 \\
\hline 4 & NDI & Mitochondria DXA & Nd1 R & 5.GGAGTACGGTTACATTCACA-3 & \\
\hline
\end{tabular}

\section{Conclusion}

In conclusion, this present study demonstrated that the liver flukes isolated from cattle-at-slaughter from the four different abattoirs in Ilorin metropolis represented Fasciola species which were categorized into two; Fasciola gigantica and Fasciola sp. due to the varying sizes of the flukes extracted from livers of infected cattle. Although, morphometric data from liver flukes supports that some were in the Fasciola sp. category, but our molecular analysis confirmed that all studied flukes were Fasciola gigantica as there was no variation in length of the ND1 gene sequences among specimens collected from hosts in different abattoirs in the studied LGA of Ilorin, North-Central, Nigeria. PCR-RFLP also showed that there were no variations in RFLP pattern to indicate a clear distinction between the two morphologically identified species of
Fasciola suggesting that they might have identical restriction map.

\section{Acknowledgement}

The authors wish to thank the Department of Zoology, University of Ilorin, Ilorin, Nigeria for making available the facilities used for this study.

\section{References}

Afshan, K., Valero, M.A., Qayyum, M., Peixoto, R.V., Magraner, A., Mas-Coma, S. (2014) Phenotypes of intermediate forms of $F$. hepatica and F. gigantica in buffaloes from Central Punjab, Pakistan. Journal of Helminthology 88(4): 1-10.

Agatsuma, T., Arakawa, Y., Iwagami, M., H onzako, Y., Cahyaningsih, U., Kang, S.Y., Ho ng, S.J. (2000) Molecular evidence of 
natural hybridization between Fasciola hepatica and $F$. gigantica. Parasitology International 49: 231-238.

Alasaad, S., Soriguer, R.C., Abu-Madi, M., El-Behairy, A., Baños, P.D., Píriz, A., Fickel, J. Zhu, X.Q. (2011) A fluorescence-based polymerase chain reaction-linked singlestrand conformation polymorphism (FPCR-SSCP) assay for the identification of Fasciola spp. Parasitology Research 108: 1513-1517.

Ali, H., Ai, L., Song, H.Q., Ali, S., Lin, R.Q., Seyni, B., Issa, G., Zhu, X.Q. (2008) Genetic characterisation of Fasciola samples from different host species and geographical localities revealed the existence of $F$. hepatica and $F$. gigantica in Niger. Parasitology Research 10(5): 1021-1024.

Amer, S., Dar, Y., Ichikawa, M., Fukuda, Y., Tada, C., Itagaki, T., Nakai, Y. (2011) Identification of Fasciola species isolated from Egypt based on sequence analysis of genomic (ITS1 and ITS2) and mitochondrial (NDI and COI) gene markers. Parasitology International 60(1): 5-12.

Baran, A.I., $\underline{\text { Akbari, H., Shahbazi, P. (2016) }}$ Field screening of Fasciola hepatica seroprevalence in sheep by indirect ELISA in East Azarbaijan province. Iranian Journal of Veterinary Clinical Sciences 10(2): 47-55.

Barker, S.C., Blair, D., Garrett, A.R., Cribb, T.H. (1993) Utility of the D1 domain of nuclear 28S rRNA for phylogenetic inference in the Digenea. Systematic Parasitology 26: 181-188

Chaudhry, U., Van Paridon, B., Shabbir, M.Z., Shafee, M., Ashraf, Yaqub, K.T. Gilleard, J. (2016) Molecular evidence shows that the liver fluke Fasciola gigantica is the predominant Fasciola species in ruminants from Pakistan. Journal of Helminthology, Cambridge University Press: 1-8.

Dar, Y., Amer, S., Mercier, A., Courtioux, B. Dreyfuss, G. (2012) Molecular identification of Fasciola spp. (Digenea: Fasciolidae) in Egypt. Parasite 19: 177182.

ElRahimy, H.H., Mahgoub, A.M., ElGebaly, N.S., Mousa, W.M. Antably, A.S. (2012) Molecular biochemical, and morphometric characterisation of Fasciola species potentially causing zoonotic disease in Egypt. Parasitology Research 111: 1103-1111.

Farjallah, S., Ben, S., limane, B., Piras, C., Amer, N., Garippa, G. Merella, P. (2013) Molecular characterisation of Fasciola hepatica from Sardinia based on sequence analysis of genomic and mitochondrial gene markers. Experimental

Parasitology 135: 471-478.

Garippa, S.F. (2009) Genetic characterisation of Fasciola hepatica from Tunisia and Algeria base. Parasitology Research 105: 1617-1621. 
Ghavami, M.B., Rahimi, P., Haniloo, A., Mosavinasab, S.N. (2009) Genotypic and Phenotypic Analysis of Fasciola Isolates. Iranian Journal of Parasitology 4(3): 6170.

Huang, W.Y. He, B., Wang, C.R. Zhu, X.Q. (2004) Characterisation of Fasciola species from Mainland China by ITS-2 ribosomal DNA sequence. Veterinary Parasitology 120: 75-83.

Hussein, A.A. and Khalifa, R.M.A. (2010) Phenotypic description and prevalence of Fasciola species in Qena Governorate, Egypt with special reference to a new strain of Fasciola hepatica. Journal of King Saud University (Science) 22: 1- 8.

Ichikawa, M., Itagaki, T. (2010) Discrimination of the ITS1 types of Fasciola spp. based on a PCR-RFLP method. Parasitology Research 106: 757 761.

Itagaki, T. Tsutsumi, K. (1998a) Triploid form of Fasciola in Japan: genetic relationships between Fasciola hepatica and Fasciola gigantic determined by ITS-2 sequence of nuclear rDNA. International Journal of Parasitology 28(5): 777-781.

Itagaki, T., Kikawa, M., Sakaguchi, K., Shimo, J., Terasaki, K., Shibahara, T., Fukuda, K., (2005) Genetic characterisation of parthenogenic Fasciola sp. in Japan on the basis of the sequences of ribosomal and mitochondrial DNA. Parasitology 131(5): 679-685.
Itagaki, T., Tsutsumi, K.I., Ito, K., Tsutsumi, Y. (1998b) Taxonomic status of the Japanese triploid forms of Fasciola: comparison of mitochondrial ND1 and COl sequences with $F$. hepatica and $F$. gigantica. Journal of Parasitology 84(2): 445-448.

Karimi, A (2008) Genetic diagnosis of Fasciola species based on $18 \mathrm{~S}$ ribosomal DNA sequences. Journal of Biological Science 8: 1166-1173.

Le, T.H., De, N.V., Agatsuma, N.T., Thi, T., Nguyen, Q.D., McManus, D.P., Blair, D. (2008) Human fascioliasis and the presence of hybrid/introgressed forms of Fasciola hepatica and Fasciola gigantica in Vietnam. International of Journal of Parasitology 38(6): 725-730.

Lin, R.Q., Dong, S.J., Nie, K., Wang, C.R., Song, H.Q., Li, A.X., Huang W.Y. and Zhu, X.Q. (2007) Sequence analysis of the first internal transcribed spacer of rDNA supports the existence of the intermediate Fasciola between F. hepatica and F. gigantica in mainland China. Parasitology Research 101(3): 813-817.

Liu, G.H., Gasser, R.B., Young, N.D., Song, H. Q., Ai, L. Zhu, X.Q. (2014) Complete

mitochondrial genomes of the 'intermediate form' of Fasciola and Fasciola gigantica, and their comparison with $F$. hepatica.Parasites and Vectors 7: 150159. 
Marcilla, A., Bargues, M.D., Mas-Coma, S. (2002) A PCR-RFLP assay for the distinction between Fasciola hepatica and F. gigantica. Molecular and Cellular Probes 16(5): 327-333.

Mas-Coma, S. (2005) Epidemiology of fascioliasis in human endemic areas. Journal of Helminthology 79(3): 207-216.

Mas-Coma, S., Valero, M.A., Bargues, M.D. (2009) Fasciola, lymnaeids and human fascioliasis, with a global overview on disease transmission, epidemiology, evolutionary genetics, molecular epidemiology and control. Advances in Parasitology 69(2): 141-146.

Mas-Coma, S., Barques, M.D., Valero, M.A. (2005) Fasciolasis and other plant-borne trematode zoonoses;. International Journal of Parasitology 35(11-12): 12551278.

Mas-

Coma, S., Valero, M.A., Bargues, M.D. (201

4) Fascioliasis. Advances in Experimental Medicine and Biology 766: 177-114.

Ohnuma, K., Yomom, T.M., Asashima, M., Kaneko, K. (2006) Sorting of cells of the same size, shape, and cell cycle stage for a single cell level assay without staining. BioMed Central Cell Biology 7: e25.

Periago, M.V., Valero, M.A., El Sayed, M., Ashrafi, K., El-Wakeel, A., Mohamed, M.Y., Desquesnes, M., Curtale, F., Mas-Coma, S. (2008) First phenotypic description of Fasciola hepatica/Fasciola gigantica intermediate forms from the human endemic area of the Nile Delta, Egypt. Infection, Genetics \& Evolution 8(1): 5158.

Periago, M.V., Valero, M.A., Panova, M., Mas-Coma, S. (2006) Phenotypic comparison of allopatric populations of Fasciola hepatica and Fasciola gigantica from European and African bovines using a computer image analysis system (CIAS). Parasitology Research 99(4): 368-378.

Prasad, P.K., Tandon, V., Biswal, D.K., Gos wami, L.M. Chatterjee, A. (2008) Molecula $r$ identification of the Indian liver fluke, Fasciola (Trematoda: Fasciolidae) based on the ribosomal internal transcribed spacer regions. Parasitology Research 103: 1247-1255.

Raina, O.K., Jacob, S.S., Sankar, M., Bhattac harya, S., Bandyopadyay, S., Varghese, A., Chamuah, J.K. Lalrinkima, H. (2013) Genet iccharacterisation of Fasciola gigantica from different geographical regions of India by ribosomal DNA markers. Journal of Parasitic Diseases 39: 1-6.

Rokni, M.B., Mirhendi, H., Mizani, A., Mohebali, M., Sharbatkhori, M., Kia, E.B., Abdoli, H., Izadi, S. (2010) Identification and differentiation of Fasciola hepatica and Fasciola gigantica using a simple PCR-restriction enzyme method. Experimental Parasitology 124(2): 209213. 
Saki, J., Khademvatan, S. and Yousefi, E. (2001) Molecular identification of animal Fasciola isolates in Southwest of Iran. Australian Journal of Basic and Applied Sciences 5: 1878-1883.

Shafiei, R., Sarkari, B., Moshfe, A. (2013) A Consistent PCR-RFLP Assay Based on ITS2 Ribosomal DNA for Differentiation of Fasciola Species. Iranian Journal of Basic Medical Sciences 16: 1266-1269.

Tsegaye, E., Begna, F., Mulugeta, S (2011) Prevalence of Bovine Fasciolosis and its Economic Significance in and Around Assela, Ethiopia. Global Journal of Medical Research 11(3): 1-7.

Velusamy, R., Singh, B.P., Ghosh, S., Chand ra, D., Raina, O.K., Gupta, S.C., Jayraw, A.K. (2006) Prepatent detection of Fasciola gigantica infection in bovine calves using metacercarial antigen. Indian Journal of Experimental Biology 44: 749-753.

Yakhchali, M., Viayeh, R.M., Baran, A.I., Mardani, K. (2015) Morphological and Molecular discrimination of Fasciola species isolated from domestic ruminants of Urmia city, Iran. Iranian Journal of Parasitology 10(1): 46-55. 